\title{
The Value Chain Analysis and Optimization Strategy of Navel Orange Industry
}

\author{
Fang Yang, Xuefeng Wang \\ School of Business and Management, Jiangxi Finance and Economics University, Nanchang, China \\ *Corresponding Author.
}

\begin{abstract}
Based on the interview survey data of the value-added activities, the value-added ratio, cost structure and profit distribution in various industry value chains of navel orange of China are analyzed. In order to increase the income of navel orange farmers and promote the industrial development, the optimization strategies are put forward from the high value-added circulation activities and vertical integration of industrial leading enterprises.
\end{abstract}

Keywords: Gannan navel orange, idustry value chain, hgh valued-added circulation activities, vrtical integration; Optimization strategy.

\section{Introduction}

The Ganan region of China is the largest planting area in the world, and the annual output in the region has become the third largest in the world. An industrial cluster has formed through integrating navel orange planting and production, storage and logistics, and deep processing. In 2020, the cultivation area of Gannan navel orange reached 1.63 million acres, with an output of 1.25 million tons for the navel orange industry cluster. The value chain of Gannan navel orange industry contains multiple functional links, such as seed selecting and breeding, technology research, material supply, planting, processing, logistics and brand marketing, etc. The value-added ratio structure of each functional link has typical characteristics of the value chain of agricultural industry, i.e., it forms the "U-shaped" valued chain curve, in which the links between seed selection and breeding, production technology research and development and brand marketing are at the high end of the $\mathrm{U}$-shaped value chain, while the value-added of the planting link is relatively small [1]. In recent years, the farmers of Gannan navel orange are facing the increasing planting risk and the investment income reduction. At the same time, a stable benefit-sharing mechanism has not been established between the business entities in different functional links, and the business entities lack a sense of cooperation in their business activities. All of these led to the high circulation cost of navel orange, and seriously restricted the further development and upgrading of navel orange industry.

In order to promote the overall value-added of the agricultural industry value chain and ensure reasonable distribution of value-added returns to farmers, domestic and foreign academics have conducted a lot of research on the composition and value-added methods of the value chain of agricultural industry. For example, Guo Heng and Sun Lei et al. (2008) conducted an empirical study on the efficiency of key circulation links to the value chain of Zigui navel orange industry and proposed that reducing the number of circulation subjects and improving the concentration of the value chain is an effective way to improve the circulation efficiency [2]. Huang Zuhui and Zhang Jing et al. (2008) analyzed the cost composition, value-added ratio and profit distribution of the value chain of pear, and fruit industry in Hebei and Zhejiang provinces in comparison, starting from the organizational structure and institutional arrangement among the core members of the industrial value chain [3]. The study concludes that the small farmers at the source of the value chain have low returns, while the middle link operators have most of the value-added returns. As the circulation of agricultural products in China is still in the stage of a

ISSN: 0010-8189

(C) CONVERTER 2020

www.converter-magazine.info 
transaction-based relationship, there is still a lack of effective integration between the various links of the industrial value chain, and the interest linkage mechanism is relatively weak. By changing the vertical structure of the value chain through the vertical collaboration of the agricultural value chain, the factor resources in the production, processing, storage, transportation, and marketing of agricultural products in the industrial value chain can be optimally allocated. By the way, transaction costs and uncertain risks can be reduced, the scale and intensive operation in the industrial value chain can be realized, and the operation efficiency of the industrial value chain can be improved [4].

Domestic and international scholars have conducted in-depth research on the labor division mode and the collaboration among business entities in different links of agricultural product value chain, such as "farmer cooperative - leading enterprise - sales market dealer" and "farmer - cooperative - supermarket" [5]. In the field of practice, local government actively supports the cultivation and growth of leading enterprises and the professional cooperatives of fruit farmers to improve the degree of organization and specialization of the value chain of agricultural products. The relevant measures include strengthening and enlarging leading enterprises, guiding the integration of resources, enhancing competitive market synergy, and forming the industrial organization mode of "leading enterprise - cooperative - farmers".

Some scholars have focused on a rational distribution mechanism of value chain benefit, and proposed related strategies to change the market vulnerability of farmers, such as forming farmers' professional cooperatives [6], improving farmers' organization, and developing contract farming [7]. Although there are cases of successful implementation of farmers' professional cooperatives in practice all over the world, there are still many limitations in the development and promotion of farmers' professional cooperatives and contract farming in China due to historical reasons and realistic development conditions. Some scholars have suggested that farmers should be encouraged and supported to directly participate in value-added distribution activities such as storage and direct marketing of agricultural products on the Internet, and directly share the value-added benefits of distribution [8]. Due to the seasonality and the centralized listing of agricultural product, the farmers often face the risk of low sales prices, resulting in a bumper crop but not a good harvest. The farmer's involvement in agricultural storage activities not only has value-added effect on their income, but also has great significance to control the price risk in the whole industry. With the development of the Internet, the farmers have more chances to conduct directs sales on the Internet. Currently, the local government in each region of China actively encourages and supports farmers to carry out circulation activities, such as agricultural products storage and direct sales on the Internet. As to Gannan navel orange, the government suggested that farmers should adopt three one-third sales strategy through the product storing to stabilize the market sales price, that is, one-third picking and selling with fresh fruits, onethird preserving to sell before the Spring Festival, and one-third storing to sell after the Spring Festival.

In conclusion, most of domestic and foreign researches have been conducted on the value-added and reasonable profit distribution in the value chain of agricultural products. In this paper, considering the distinct characteristics of the value chain of Gannan navel orange, we attempt to focus on analyzing the value-added, cost composition, and profit distribution in the value chain, and propose suggestions on value chain optimization strategy. The objective of the optimization strategy is to realize the rationalization and close coordination among the participants of Gannan navel orange industry, thereby improve the operation efficiency of value-added activities, and enhance the overall industrial competitiveness.

\section{Analysis of Value Chain of Gannan Novel Orange Industry}

\subsection{Analytical design}

This study takes into account several factors, such as the cultivation area, production yield, distribution channel

ISSN: 0010-8189

(C) CONVERTER 2020

www.converter-magazine.info 
and market structure. Two counties Xunwu and Anyuan, which are the representative of the value chain of Gannan navel orange, are selected as the research subjects. Since there are many complex links in the value chain of navel orange, such as production, wholesale, retail and logistics. The related subjects include fruit farmers, brokers, distributors and retailers, etc. The structure of the value chain of Gannan navel orange is diversified (see Fig. 1).

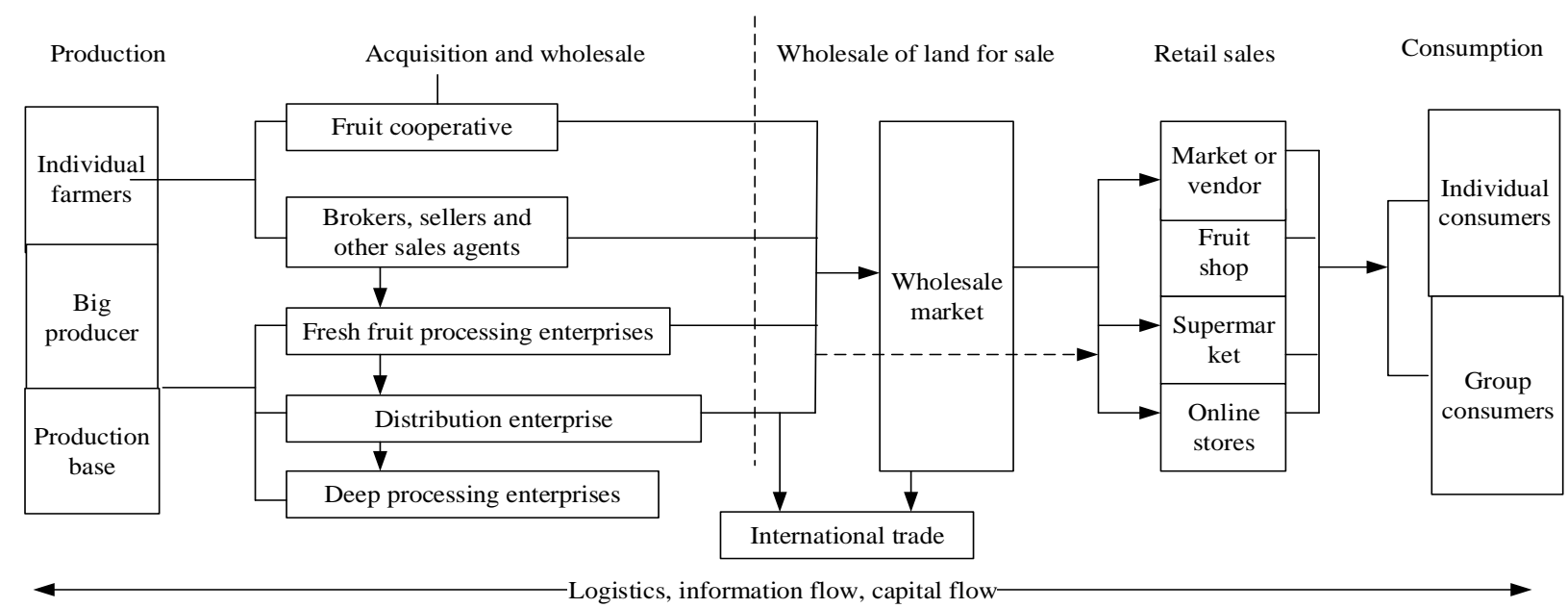

Fig 1: Main components of the value chain of Gannan navel orange industry

The pre-production link of the value chain in Gannan navel orange industry is undertaken by the local government, and is not discussed in detail. The data used in the paper, except for some from the public information of Ganzhou City Fruit Bureau, are from several field studies and in-depth interviews conducted by the research team since 2014. The subjects of this study include fruit farmers, cooperatives, brokers, processing enterprises, origin dealers, distribution dealers, retailers, and local government department which are involved in the production and distribution of Gannan novel orange. The corresponding interview outline is determined according to the different subjects of the interview, and the specific contents include: first, it is related to the characteristics of the subjects of each link of the value chain itself, including the basic information of the interviewers, the basic situation of production and operation; secondly, it is the cost information related to the production and circulation links of the value chain; thirdly, it is the sales price and profit level of each link, as well as the evaluation of the current situation, etc.

\subsection{Value chain link analysis}

\subsubsection{Fruit farmer production links}

The basic characteristics of the sample of fruit farmers in the field research are shown in Table 1. From the data, we know that the average planting area of fruit farmers is 16.08 acres; the fruit farmers with a planting area of less than 10 acres scale account for about $35 \%$ of the total sample; the proportion of fruit farmers with 10-20 acres scale is 45\%; and the number of fruit farmers with more than 21 acres together accounts for 20\%; the income of fruit farmers from selling navel orange accounts for $57 \%$ of their total agricultural income and $46 \%$ of their total household income, which shows that the cultivation and sale of navel orange is the most important source of agricultural income for local fruit farmers. In recent years, the growing area of navel orange has been relatively more stable.

Table 1. Basic characteristics of fruit farmer research subjects

\begin{tabular}{|c|c|c|}
\hline $\begin{array}{c}\text { Navel orange planting area (Unit: } \\
\text { acres) }\end{array}$ & $\begin{array}{c}\text { Average percentage of navel } \\
\text { orange revenue }\end{array}$ & Sources of land \\
\hline
\end{tabular}

ISSN: 0010-8189

(C) CONVERTER 2020

www.converter-magazine.info 
Volume 2021, No. 2

\begin{tabular}{ccccccc}
\hline $\begin{array}{c}\text { Less than } \\
10\end{array}$ & $10-20$ & $\begin{array}{c}\text { More than } \\
21\end{array}$ & $\begin{array}{c}\text { Percentage of } \\
\text { total } \\
\text { agricultural } \\
\text { revenue }\end{array}$ & $\begin{array}{c}\text { Percentage } \\
\text { of household } \\
\text { revenue }\end{array}$ & $\begin{array}{c}\text { Self- } \\
\text { owned }\end{array}$ & $\begin{array}{c}\text { leased } \\
35 \%\end{array}$ \\
\hline
\end{tabular}

Data source: based on data from the survey of Gannan navel orange growers from 2017 to 2019

Considering that it takes more than four years from transplanting seedlings to mature and stable production of navel orange, the initial input costs of orchards are not considered for the time being to ensure the consistency and comparability of production cost data of farmers. After the orchard enters the stable production period, the production costs in each fruiting season mainly include material input costs and labor costs. The various cost inputs (average data) per unit area (667 square meters ) in the research area from 2017 to 2019 are shown in TABLE 2.

The data in TABLE II shows that fertilizer input and labor cost account for a large proportion of the total cost, and the total input cost per unit area of navel orange cultivation shows a trend of the increasing year by year, among which fertilizer and labor cost grow faster. It is also found that the labor price shows an increasing trend, which has become an important factor limiting the development of the navel orange industry.

Table 2. Composition of various cost inputs per unit area (A total of $667 \mathrm{~m} 2$ ) of fruit farmers in the survey area Unit: Yuan

\begin{tabular}{|c|c|c|c|c|}
\hline \multirow{2}{*}{\multicolumn{2}{|c|}{ Cost input items }} & \multicolumn{3}{|c|}{ Year of production } \\
\hline & & 2017 & 2018 & 2019 \\
\hline \multirow{5}{*}{$\begin{array}{l}\text { Material input } \\
\text { costs }\end{array}$} & Fertilizer input & 889 & 964 & 1013 \\
\hline & $\begin{array}{c}\text { Agricultural fertilizer } \\
\text { input }\end{array}$ & 331 & 343 & 345 \\
\hline & Pesticide input & 372 & 384 & 390 \\
\hline & $\begin{array}{c}\text { Cost of machinery } \\
\text { and material supplies }\end{array}$ & 94 & 94 & 97 \\
\hline & Total material costs & 1686 & 1785 & 1950 \\
\hline \multirow{3}{*}{ Labor Costs } & $\begin{array}{l}\text { Management of labor } \\
\text { costs }\end{array}$ & 472 & 546 & 614 \\
\hline & $\begin{array}{c}\text { Harvesting labor } \\
\text { costs }\end{array}$ & 257 & 274 & 309 \\
\hline & Total labor cost & 729 & 820 & 923 \\
\hline \multicolumn{2}{|c|}{ Total Cost } & 2415 & 2605 & 2695 \\
\hline
\end{tabular}

Note: Based on research data

\subsubsection{Fruit farmers marketing link}

The overall production and sale of the sample navel orange farmers are shown in Table 3. The average mu production of navel orange of the sample farmers was $1507 \mathrm{~kg}$, and the average selling price was $5.33 \mathrm{yuan} / \mathrm{kg}$, with $92.5 \%$ of fresh fruit sales and $7.5 \%$ of stored fruit. In the storage process, the fruit farmers face the market price risk and about $5 \%$ loss rate of navel orange. Due to the climate, small and large years, and fruit tree disease, etc., the yield of navel orange in different years season varies greatly. It also can be found from investigation that the fruit farmers usually take case transactions, and those with small planting areas use one-time transaction, while only the fruit farmers with larger planting areas or those with storage facilities can trade two to three times. The harvesting time of navel orange is concentrated in November. with a large number of medium-ripening varieties on the market, the market price of the navel orange will drop for a period of time, and then it rose gradually.

The market participation of the sample fruit farmers is shown in Table 4 (average data from 2017 to 2019), and the dealers in the table refer to both field and local dealers (excluding local fruit companies). The main sales channel of the sample fruit farmers in this study is through dealers entrusting brokers to make field purchase, with average

ISSN: 0010-8189

(C) CONVERTER 2020

www.converter-magazine.info 
Volume 2021, No. 2

proportion of $82.5 \%$. Only about $9 \%$ of the fruit farmers sold directly to consumers. In recent years, with the local government vigorously carrying out online new media promotion and e-commerce sales for integrated online and offline marketing, the scale of direct sale of navel orange has increased year by year. Although the direct sale channel may bring higher logistics cost than traditional channel, the marginal profit of direct sale is still higher than other sale channels due to its higher selling price and the elimination of various intermediate link costs.

Table 3 Overall production and sales of sample fruit farmers from 2017 to 2019

\begin{tabular}{cccccc}
\hline \multirow{2}{*}{ Years } & $\begin{array}{c}\text { Unit yield } \\
\text { during the } \\
\text { production } \\
\text { season }\end{array}$ & $\begin{array}{c}\text { Proportion of } \\
\text { fresh fruit } \\
\text { sales }\end{array}$ & $\begin{array}{c}\text { Proportion of } \\
\text { stored fruit } \\
\text { sales }\end{array}$ & Sales price & $\begin{array}{c}\text { Percentage of } \\
\text { cash } \\
\text { transactions }\end{array}$ \\
\cline { 2 - 6 } & Unit: kg/mu & $(\%)$ & $(\%)$ & Unit: Yuan/kg & $(\%)$ \\
\hline 2017 & 1464 & 93.5 & 6.5 & 4.5 & $100 \%$ \\
2018 & 1656 & 92.6 & 7.4 & 5.2 & $100 \%$ \\
2019 & 1402 & 91.4 & 8.6 & 6.3 & $100 \%$ \\
Average & 1507 & 92.5 & 7.5 & 5.33 & $100 \%$ \\
\hline
\end{tabular}

Note: Calculated based on research data

Table 4 Proportion of sample fruit farmers' Gannan navel orange sales market participation methods (unit: \%)

\begin{tabular}{ccccc}
\hline Research Subjects & Dealers & $\begin{array}{c}\text { Fruit companies (or } \\
\text { cooperatives) }\end{array}$ & Consumers & $\begin{array}{c}\text { Selling to more } \\
\text { than two buyers }\end{array}$ \\
\hline Xunwu County & 81 & 24 & 11 & 14 \\
\hline Anyuan County & 84 & 25 & 7 & 18 \\
\hline Average value & 82.5 & 24.5 & 9 & 16 \\
\hline
\end{tabular}

Note: Calculated based on research data

\subsubsection{Sales Chain at the Place of Origin}

In the wholesale link of the value chain of Gannan navel orange industry, there are many subjects with diversified characteristics, including brokers, professional cooperatives, origin dealers, fruit companies, and so on. The brokers provide local and foreign dealers with services such as acquisition information, organizing sources of goods and packaging, and usually charge a certain commission according to the transaction volume, with an average commission of about RMB 0.06-0.07 yuan per kilogram of navel orange in recent years. In the case of Gannan navel orange with wide regional distribution and fragmented business patterns, brokers had played an important role in improving the efficiency of navel orange trading, but the role of brokers has weakened as the origin dealers have mastered local production information and procured navel orange on their own. The cooperatives of Gannan navel include loose and close cooperative, among which loose cooperatives provide services such as sales, planting technology, and agricultural materials for farmers, but do not sign contracts with merchants for the purchase and sale of navel orange, and members of the cooperatives can sell navel orange on their own. The close cooperative is the fruit company, which is equivalent to the form of "leading enterprise (fruit company)-cooperative", and plays an important role in the circulation of Gannan navel orange. Besides, its operation form is equivalent to the fruit company.

The dominant market players in the wholesale sales of Gannan navel orange at origin are distributors or fruit companies engaged in the acquisition and sale of navel orange. These market players' outstanding ability is to grasp information of products and market demand, and possess distribution resources such as storage facilities, sales channels, and brands. The main difference between general distributors and fruit companies is that fruit

ISSN: 0010-8189

(C) CONVERTER 2020

www.converter-magazine.info 
companies have navel orange processing lines and storage facilities, while other distributors acquire navel orange locally and entrust them to local processing enterprises for sorting and processing. The origin dealers (fruit companies) acquire Gannan navel orange from farmers through their employees or brokers, and after carrying out activities such as fruit screening, grading, processing, and storage, then they sell them in stages according to market prices. As present, the sale channels and objects of origin dealers (fruit companies) are diversified, including distributors in distribution areas, supermarkets, foreign merchants, etc. With the development of the Gannan navel orange industry and the positive influence of the government, the origin dealers have been increasing their specialization and have built various types of storage warehouses, including constant temperature, refrigerated freshness storage, ordinary storage, and gas-conditioned storage; and established sorting and waxing packaging production lines. In recent years, the form of integration between the origin dealers and the sellers of Gannan navel orange has been emerging, forming an effective information transfer and guidance mechanism between the origin and the sellers.

\subsubsection{Sales Chain at the Place of Sale}

The whole dealers in sale area specialized in navel orange sales and wholesale business. According to field research, the main target of local distributors is traditional retailers (fruit stores), with a proportion of nearly $64 \%$ of total sales, while the remaining $22 \%$ of total sales are sold to supermarkets and $14 \%$ to hotels, restaurants, and hospitals. The fixed operating costs of the wholesale distributors incudes hiring cost, store and ware house rentals, communication cost, and truck-related costs, etc. Since it is difficult to obtain accurate data of each cost item, the overall cost can be determined directly. Taking the Shanghai wholesale vegetable market as an example, the cost of the wholesale sales link of Gannan navel orange is 0.6 yuan per kilogram.

The main bodies engaged in the retail business at the place of sale include mainly traditional retailers (fruit stores) and modern retailers (supermarkets). Among them, fruit stores purchase kinds of fruits from wholesale markets with cash payment, and are responsible for logistics and transportation. Supermarkets have more strict requirements on the sorting grade and quality of navel orange, and their procurement costs are relatively high. We can estimate gross profit margin of supermarkets as $12.9 \%$ released by the Ministry of Commerce. The operating costs of fruit stores include store rent, transportation costs, staff costs, etc. It is difficult to accurately count the costs specifically on a single fruit product, which can be judged by estimating its gross margin at $10 \%$.

\subsection{Value-Added Analysis of Value Chain}

Since the value-added activities of each link of the value chain of the Gannan navel orange industry can be undertaken by different participating subjects, the diverse value chains can be formed. In this paper, without affecting the overall analysis, various forms of value chain patterns are categorized into the corresponding three typical forms based on the length of the value chain (see Table 5), and the value-added and cost structures of the three types of value chains and the profit distribution among the participating subjects are analyzed based on the research data in 2017.

Table 5 Value chain types and sales volume ratio of Gannan navel orange industry

\begin{tabular}{ccc}
\hline Types & Value Chain Components & Sales ratio \\
\hline Type I & Fruit farmers - origin distributors - destination distributors - traditional or & $70.22 \%$ \\
& modern retailers & \\
Type II & Fruit farmers - distributors - retailers (traditional/modern), exporters, & $20.75 \%$ \\
& large customers & \\
Type III & Farmer-consumer or Farmer-distributor-consumer & $9.03 \%$ \\
\hline
\end{tabular}

2.3.1 Fruit farmers-origin distributors-destination distributors-traditional or modern retailers

ISSN: 0010-8189

C C CONVERTER 2020

www.converter-magazine.info 
This type of industrial value chain is the main form of the value chain for Gannan navel orange, which accounts for more than $50 \%$ of market sales and circulates. Its value-added, cost, and profit distribution are shown in TABLE VI. The value-added of each link represents the difference between the sales price and purchase price; the valueadded ratio represents the proportion of value-added of each link to the total value-added of the whole value chain; the new cost represents the circulation cost generated among each link.

Table 6 Proportional composition of value chain type I value-added structure of Gannan navel orange Unit: Yuan/kg

\begin{tabular}{cccccc}
\hline \multirow{2}{*}{ Value-added structure } & Fruit & Producer & Sales & \multicolumn{2}{c}{ Retailers } \\
\cline { 5 - 6 } & Farmers & Distributors & Distributors & $\begin{array}{c}\text { Traditional } \\
\text { retailers }\end{array}$ & $\begin{array}{c}\text { Modern } \\
\text { Retailers }\end{array}$ \\
\hline Purchase price or cost & 1.92 & 6.10 & 8.85 & 9.47 & 9.65 \\
Average sales price & 6.10 & 8.85 & $9.47(9.65)$ & 11.80 & 12.15 \\
New cost & 0.05 & 1.95 & 0.20 & 0.60 & 1.00 \\
Value added & 4.18 & 2.75 & $0.62(0.80)$ & 2.33 & 2.50 \\
Value-added percentage & 42.31 & 27.83 & 6.28 & 23.58 & - \\
$(\%)$ & 40.86 & 26.88 & 7.82 & - & 24.44 \\
Profit & 4.13 & 0.80 & 0.46 & 1.73 & 1.50 \\
\hline
\end{tabular}

Note: The quality and grade of navel orange sold to traditional retailers and modern retailers in the table are different, so the average sales price and value-added are different. Two data are listed separately in the table, where profit is the weighted average of profit and value-added of sales to two downstream customers, while the valueadded ratio and profit distribution ratio are calculated separately.

From the analysis in TABLE VI, it can be seen that the value-added of the distribution link accounts for a larger proportion of the total value-added of the industry value chain. In terms of the value-added ratio of each link, the value-added of the fruit farmer link is the largest, the origin distributor link is the second largest, and the outlet distributor is the smallest. For the composition of the cost structure of each link, the storage and circulation cost of navel orange per unit weight is higher than the production cost, such as the distribution cost of the original link up to 1.95 yuan per kilogram. Most market sale is through traditional retailers (fruit stores), which sell at prices slightly lower than those of integrated supermarkets. Therefore, the supermarkets do not have a competitive advantage in terms of sales profit due to their higher purchasing and operating costs.

As to the profit distribution in the industrial value chain, the fruit farmer has the largest profit distribution with a profit of RMB 4.13 per kg, followed by traditional retailers and modern retailers whose profits are RMB 1.73 per $\mathrm{kg}$ and RMB 1.50 per $\mathrm{kg}$ navel orange, respectively. From the point of view of profit distribution, farmers made the largest profit per unit weight of navel orange, if we further consider the cost of farmers' own labor inputs, the initial investment in orchards, land contract rights, and limited production, the level of farmers' income still needs to be improved.

\subsubsection{Fruit farmers-distributors-retailers (traditional/modern), exporters, large customers}

Due to the increasing strength of distributors in the production area of Gannan navel orange, the distributors in the distribution area directly carrying out the acquisition and processing of navel orange in the production area. So the distributors with integrated production and distribution area are gradually formed, which constitute a shorter value chain. The distributors undertake both the business of acquisition in the production area and sales in the distribution area. The cost-benefit and value-added ratios of each of them are shown in TABLE VII.

Table 7 Proportional composition of value-added structure of Gannan navel orange value chain type II Unit: Yuan/kg

ISSN: 0010-8189

C C CONVERTER 2020

www.converter-magazine.info 


\begin{tabular}{ccccc}
\hline & & & \multicolumn{2}{c}{ Retailers } \\
\cline { 4 - 5 } Value Added Structure & Fruit Farmers & Distributors & $\begin{array}{c}\text { Traditional } \\
\text { retailers }\end{array}$ & $\begin{array}{c}\text { Modern } \\
\text { Retailers }\end{array}$ \\
\hline Purchase price or cost & 1.92 & 6.10 & 9.47 & 9.65 \\
Average sales price & 6.10 & $9.47(9.65)$ & 11.80 & 12.15 \\
New cost & 0.05 & 1.85 & 0.60 & 1.00 \\
Value-added & 4.18 & $3.37(3.55)$ & 2.33 & 2.50 \\
Value-added ratio $(\%)$ & 42.31 & 34.11 & 23.58 & - \\
Profit & 40.86 & 34.70 & - & 24.44 \\
\hline
\end{tabular}

As can be seen from Table 7, the cost per unit weight of navel orange distributor link is RMB 1.85 yuan per kilogram, which achieves cost-saving of 0.30 yuan per kilogram compared to the total cost of 2.15 yuan per kilogram for origin and sales distributor in the first type of industry value chain. The distributor segment gains more profit, which reaches $1.57 \mathrm{RMB} / \mathrm{kg}$. The distributor becomes the dominant player in the value chain of the navel orange industry as it holds the market information of the production and distribution areas, and has the distribution resources such as storage facilities, sales channels, and brands.

\subsubsection{Farmer-consumer or farmer-distributor-consumer}

With the rise of online shopping in recent years, the online sales of Gannan navel orange have continued to grow, while some fruit farmers and distributors directly connect with exporters or large group customers, and many new sales models that omit the traditional wholesale and retail links have emerged, including group purchase, online sales, and sightseeing and picking. The cost-benefit and value-added ratios of the subjects in each link are shown in Table 7 .

In this study, we focus on a new marketing model in which consumers usually have higher requirements for the quality of navel orange, as well as specific distribution processing and packaging, and better logistics and information services, all of which increase their transaction costs. In the "farmer-consumer" value chain, the farmer is the dominant player in the value chain, undertaking most of the value-added activities and making a profit of RMB 5.08/kg per unit weight of navel orange; in the "farmer-distributor-consumer" value chain, the distributor is the dominant player in the value chain. In the "farmer-distributor-consumer" value chain, the distributor is the value chain leader, and the profit per unit weight of navel orange is RMB $4.13 / \mathrm{kg}$ and RMB $2.00 / \mathrm{kg}$ for the farmer and the distributor, respectively. Due to the reduction of value chain links, all value chain leaders gained higher profits.

Table 8 Proportional composition of value-added structure of Gannan navel orange value chain type III Unit:

\begin{tabular}{cccc} 
& \multicolumn{2}{c}{ Yuan/kg } & \\
\hline \multirow{2}{*}{ Value Added Structure } & Farmer-Consumer & \multicolumn{2}{c}{ Farmers-Dealers-Consumers } \\
\cline { 2 - 4 } & Fruit Farmers & Fruit Farmers & Dealers \\
\hline Purchase price or cost & 1.92 & 1.92 & 6.10 \\
Average sales price & 11.4 & 6.10 & 11.40 \\
New cost & 4.5 & 0.05 & 3.40 \\
Value Added & 9.58 & 4.18 & 5.40 \\
Percentage of value added & $100 \%$ & $41.88 \%$ & $58.12 \%$ \\
Profit & 5.08 & 4.13 & 2.00
\end{tabular}

ISSN: 0010-8189 


\subsubsection{Analysis of value chain problems and research implications}

According to the analysis in the previous section, the value-added returns of the circulation link in the value chain of the three types of Gannan navel orange industry are greater than those of the production link. The circulation link realizes the effective connection between production and consumption, and takes the core position in the industrial value chain. From the perspective of the overall cost of the industry value chain, the distribution cost of the value chain of "fruit farmer - origin dealer - destination dealer - traditional or modern retailer" is the highest. The "farmer-consumer or farmer-distributor-consumer" value chain has the second-lowest distribution cost. It has the least number of links in the value chain and effectively connects farmers and markets, but the distribution and sales volume limit the economic transportation needs of large quantities, resulting in high transportation and sales time costs per unit of commodity. The "farmer-distributor-retailer (traditional/modern), exporter, large customer" value chain can obtain the lowest distribution cost.

From the perspective of the profits obtained by each subject, the absolute value of profits obtained by farmers per unit of navel orange in all three types of navel orange industry value chains is the highest, while the absolute value of profits obtained by retailers is the lowest. As far as the value-added distribution is concerned, the profits of farmers are not squeezed and encroached by other participating subjects in the value chain. However, there are significant differences in the profit cycle between fruit farmers and intermediaries, and retailers. The profitability (production) cycle of fruit farmers is up to 5 months, during which they continuously invest in production materials and labor, and also take natural risks and market price risks.

Based on the value-added analysis of each link of the three types of value chains, the following research ideas can be provided for fruit farmers to increase their income and the development of the Gannan navel orange industry. Given that the value-added returns of the distribution link are greater than those of the production link, they are in the core position in the value-added of the industrial value chain. The impact of different distribution channel choices on the value-added of production and marketing links of fruit farmers is not obvious. Therefore, farmers should be strongly supported and encouraged to participate in high-value distribution value-added activities such as navel orange harvesting, storage, and direct network sales to effectively increase their profitability. At present, the circulation channel of Gannan navel orange has basically realized the effective connection between production and consumption. However, most of the subjects in different value chains remain in temporary market trading relationships and have not yet formed a stable cooperation mechanism of risk-sharing and benefit-sharing. The value chain lacks leading distribution enterprises with influence and voice in the navel orange market at home and abroad. Therefore, we should further establish and strengthen the coordination mechanism of the main bodies, and improve the industrialization organization of the leading distribution enterprises through vertical integration.

\section{Analysis of Fruit Farmers' Involvement in High Value-Added Navel Orange Distribution Activities}

Navel orange storage and network direct marketing are both high value-added navel orange circulation activities. The two activities influence, support and promote each other. The fruit farmers involved in the above-mentioned high value-added circulation activities can obtain the following benefits: fruit farmers involved in network direct marketing can accelerate the dissemination of product information, supply, and demand, market prices, improve the real-time and interactive information exchange between the two sides of the transaction, and break through the time and space limitations of information dissemination and information disparity. It is beneficial for farmers to obtain market information. What is more important is that the fruit farmers involved in direct network marketing can choose their customers rationally according to the market price, and enhance their price negotiation ability. The network direct marketing provides a platform for fruit farmers to trade directly with the demand side. Fruit farmers can directly contact the demand side through the network, broaden the sales market, enhance the brand image of their products, reduce the need for traditional physical infrastructure equipment, and help fruit farmers reduce transaction costs and enjoy brand spillover benefits. Fruit farmers involved in navel orange storage can

ISSN: 0010-8189

(C) CONVERTER 2020

www.converter-magazine.info 
extend the sales cycle of navel orange with fresh and perishable characteristics through storage and preservation measures, and reasonably choose the time to sell according to the market price in that cycle, thus improving the price negotiation ability of fruit farmers and increasing their income.

When participating in navel orange storage and network direct marketing, farmers will also face the threshold barriers (initial investment), cost changes, and possible market price fluctuation risks of participating in high valueadded distribution activities. The decision of whether or not to participate in high value-added distribution activities depends on the trade-off between the additional costs invested, the market risks faced and the expected benefits, which can be described as the following cost-benefit trade-off analysis.

Let $L$ be the expected gain for the fruit farmer's involvement in high value-added distribution activities, $L^{*}$ represents earnings from non-involvement in high value-added distribution activities, and $\hat{L}$ be the possible additional costs and risks for fruit farmers involved in high value-added distribution activities. Then the decision function of the fruit farmers' involvement in high value-added distribution activities can be expressed as $D(L)=\left\{L-L^{*} \geq \hat{L}\right\}$

. In other words, only when the difference between the expected benefits of high value-added distribution activities and the benefits of non-involvement is greater than the increased costs and risks of high value-added distribution activities, the farmers will decide to participate in high value-added distribution activities. The increased costs and risks depend on the farmers' own internal factors and the external environment. The farmers' internal factors are mainly reflected in two aspects: marketing concepts and market technology capabilities. The marketing concept of farmers has a significant impact on their involvement in the high-value activities of navel orange distribution. As farmers need to make some early investment and technical reserves to participate in navel orange high-value activities. But if individual farmers have limited scale of operation, they cannot recover their premise investment and make profit in the short term, and may even bear the risk of operating at a loss, which will lead to the low willingness of farmers to participate in network direct marketing and navel orange storage. For market technology and ability, most of the fruit farmers have not yet mastered complete network marketing technology and storage technology, resulting in their lack of grasp of the sale timing of navel orange. Besides, the behavior of farmers to participate in high value-added activities in the distribution of agricultural products is influenced by various factors such as risk attitude, the scale of cultivation, marketing of agricultural products, level of storage technology, transportation conditions, and whether the government provides free training in storage technology. And the behavior of farmers changes continuously with these factors.

External environmental barriers are mainly reflected in the following aspects. First, lack of perfect logistics infrastructure. Since the production of Gannan navel oranges has strong seasonal and regional characteristics, and the products are perishable, direct sales and storage of navel oranges on the network require a perfect modern logistics and distribution system for support. Second, the network direct marketing infrastructure and conditions are still backward. The weak of network technology, network security management, and other aspects, cannot meet the objective requirements of network marketing. Mainly reflected in an efficient and convenient online trading platform for agricultural products is lacking, part of the agricultural website and agricultural e-commerce website applications are too small. Third, the lack of direct marketing talent. The network direct marketing mode requires talents with rich experience in network marketing and promotion as well as understanding the operation and management of agricultural products production.

\section{Veertical Integration Analysis of Leading Companies}

The distribution enterprises play leading roles from the importance in the industrial value chain of Gannan navel.

ISSN: 0010-8189

C C CONVERTER 2020

www.converter-magazine.info 
However, the scale of distribution enterprises in Gannan is generally small, and lack of influence in the market. Therefore, it should to further establish and strengthen the coordination mechanism of the main bodies in the industrial value chain, and continuously improve the industrialization organization of the leading enterprises. The leading enterprises can be strengthened from vertically integrated expansion and horizontally integrated expansion, respectively. The horizontal integration is mainly through the alliance and reorganization among similar enterprises to achieve economies of scale. Vertical integration, on the other hand, refers to the expansion of the leading enterprises' business activities in the production and sales of navel orange to achieve forward and backward expansion, which in essence is the transformation of the buyer-seller transaction relationship in the market into an internal management relationship. This section will analyze the feasibility of vertical integration of the leading enterprises.

The vertical integration of leading enterprises is conducive to reducing information failure or distortion in the navel orange circulation market, and makes all links of the industry chain to form a close cooperative relationship. The timely and accurate transmission of market demand information of all links of the value chain can reduce the transaction costs and the circulation loss. Through the leading role of leading enterprises, the scattered farmers, cooperatives, production bases, processing enterprises, distribution enterprises, and retail enterprises can be united to form economies of scale and reduce the cost of production and circulation of navel orange.

The neoclassical economics and neo-institutional economics are the theoretical bases for the decision motive of vertical integration behavior of leading enterprises in Gannan navel orange industry. Neoclassical economics believes that obtaining economies of scope and reducing production costs are the most intuitive explanations for vertical integration, while neo-institutional economists attribute vertical integration to the saving of transaction costs and believe that vertical integration of enterprises can avoid high transaction costs due to the market mechanism. In conclusion, vertical integration can help achieve economies of scale by resolving information asymmetries among firms, eliminating imperfect competition, and reducing transaction costs.

The decision process of vertical integration of leading enterprises can be briefly analyzed as follows: Considering that the value chain of the navel orange industry consists of only two enterprises upstream and downstream, each enterprise pursues its own maximal interest according to the principle of marginal production. When the value chain is vertically integrated, a single firm produces both intermediate and final agricultural products. Besides, when the value chain is vertically decomposed, the upstream and downstream firms are responsible for producing intermediate and final agricultural products, respectively. Let $p_{1}$ and $p_{2}$ respectively be the unit sales prices of intermediate and final agricultural products, and the unit production costs be $C_{p_{1}}$ and $C_{p 2}$ respectively. The total unit production costs of upstream and downstream firms are reduced after vertical integration by $C_{v}$ (Excluding economies of scale in the case of vertical decomposition). The market consumption demand function for the final product can be expressed as $q=d\left(p_{2}\right)=1-p_{2}\left(0<p_{1}<p_{2}<1\right)$.

In the case of vertical decomposition, the unit transaction costs incurred by upstream and downstream companies respectively are $C_{t 1}$ and $C_{t 2}$. The first-order condition for profit maximization by downstream firms' yields is $p_{2}^{*}=\frac{3+C_{p 1}+C_{p 2}+C_{t 1}+C_{t 2}}{4}$. The $p_{1}^{*}=\frac{1+C_{p 1}-C_{p 2}-C_{t 1}+C_{t 2}}{2}$

can be obtained from the first-order condition for profit maximization of upstream firms. In the case of vertical integration, the first-order condition for firm profit maximization yields $p_{2}^{*}=\frac{1+C_{p 1}+C_{p 2}-C_{v}}{2}$, and the total firm profit is $\frac{\left(1-C_{p 1}-C_{p 2}+C_{v}\right)}{4}$.

From the above analysis, it is clear that the profit of a firm's vertical integration is greater than the sum of the profit

ISSN: 0010-8189

C C CONVERTER 2020

www.converter-magazine.info 
of the two vertically decomposed firms. Vertical integration of leading enterprises can not only reduce production and transaction costs, thus increasing enterprise profits, but also increase consumer surplus. When decomposed vertically, each navel orange distribution subject makes decisions from its own profit perspective, which generates negative vertical externality to other link subjects and leads to a reduction in profit for each distribution link.

\section{Conclusion}

According to the aforementioned analysis, the distribution link is at the core of the value chain of the Gannan navel orange industry. The effective involvement of farmers in the direct marketing and storage activities in the distribution chain can significantly improve their returns. The reduction of navel orange production and distribution cost can be realized from the vertical integration of leading enterprises. Therefore, the involvement of farmers in high value-added distribution activities in the industrial value chain and the vertical integration of industrialized leading enterprises can promote the development of the Gannan navel orange industry, which is also an important way for farmers to increase their income.

For farmers involving in the high value-added activities, such as direct marketing and storage activity, the government should support them from the following aspects. First, we should strengthen the guarantee system of network marketing for Gannan navel orange. To speed up the construction of network infrastructure in rural areas by playing the leading role of the government. To realize the standardization of agricultural products in network marketing by establishing the quality standard system of Gannan navel orange. Second, the logistics network system should be established and improved. On the basis of perfect storage facility nodes and transportation channels, the third-party logistics enterprises and commercial storage enterprises can be encouraged to develop to realize the sharing of social logistics resources. Third, strength the professional technical training for fruit farmers to improve the quality and ability of the high value-added circulation activities such as direct marketing and storage of navel oranges in the network. The fruit farmers can be encouraged to rely on farmers' cooperatives and other means to carry out the cooperative operations, expand the scale of operation and realize resource sharing, to reduce the initial input costs and avoid risks.

For the vertical integration of leading enterprises of Gannan navel orange industry, the government should provide the following supports. First, based on the existing large and medium-sized industrialized leading enterprises of Gannan navel orange, encourage and support vertical integration through mergers, reorganization, acquisition, holding, and cross-regional cooperation. Implement various policy measures and relevant financial and tax preferential policies to strengthen and enlarge leading enterprises, realize enterprise-scale and intensive operation, improve industrial concentration, and cultivate famous Gannan navel orange brands with high market share and wide influence. Second, in order to enhance the farmers' voice, price negotiation position and management ability, a close interest linkage mechanism with professional cooperatives and farmers can be established by the "company - cooperative - farmers" organization model. The legitimate rights and interests of all parties can be protected by improving relevant laws and regulations, and intervening in the interest mediation between leading enterprises and farmers.

\section{References}

[1] H. Chen. "Industrial upgrading in the perspective of value chain division of agricultural products distribution," Seeking, 2: 20-22. 2008.

[2] H. Guo, L. Sun, C.J. Qi. "An analysis of the value chain and distribution efficiency of agricultural products--an empirical study of Zigui navel orange distribution market. Journal of Economic Research," vol. 16, pp. 33-35, 2008.

[3] Z.H. Huang, J. Zhang, Z.G. Chen. "Value chain analysis of Chinese pear and fruit industry," China

ISSN: 0010-8189

(C) CONVERTER 2020

www.converter-magazine.info 
Rural Economy, vol. 7, pp. 63-72, 2008.

[4] S.J. Li. "Empirical analysis of benefit distribution mechanism of agricultural product distribution chain," Agricultural Technology Economy, vol. 11, pp. 108-114, 2010.

[5] Z.H. Wang. "Analysis of the basic forms of expansion of agricultural product distribution enterprises in China,” Shandong Social Science, vol. 4, pp. 84-87, 2008.

[6] C.Y. Xia, J.Q. Xue. "Agricultural industrialization model, benefit distribution and farmers' income," Research on Finance and Economics, vol. 11, pp. 31-38, 2008.

[7] D.H. Hu, Z.G. Chen, Q.Z. Sun. "The impact of contract production mode on farmers' income and food safety: Taking the apple industry in Shandong Province as an example," China Rural Economy, vol. 11, pp.17-25, 2006.

[8] C.Q. Tu. "Analysis of influencing factors of farmers' involvement in high value-added activities in agricultural distribution," Business Economics and Management vol. 271, no. 5, pp. 12-2, 2017. 